Volcanic settings and their reservoir potential: an outcrop analogue study on the Miocene Tepoztlán Formation, Central Mexico

\author{
Nils Lenhardt ${ }^{\mathrm{a}, *}$, Annette E. Götz ${ }^{\mathrm{b}}$
}

${ }^{\mathrm{a}}$ Department of Geology, University of Pretoria, Pretoria, South Africa

${ }^{\mathrm{b}}$ Institut für Angewandte Geowissenschaften, Technische Universität Darmstadt,

Darmstadt, Germany

* Corresponding author: Department of Geology,

University of Pretoria,

Pretoria 0002

South Africa

Tel.: $\quad++27(0) 124203310$

Fax: $\quad++27(0) 123625219$

E-Mail: nils.lenhardt@up.ac.za

\author{
Manuscript accepted by \\ Journal of Volcanology and Geothermal Research
}

Second Version:

February 28, 2011 


\title{
Volcanic settings and their reservoir potential: an outcrop analogue study on the Miocene Tepoztlán Formation, Central Mexico
}

\begin{abstract}
The reservoir potential of volcanic and associated sedimentary rocks is less documented in regard to groundwater resources, and oil and gas storage compared to siliciclastic and carbonate systems. Outcrop analogue studies within a volcanic setting enable to identify spatio-temporal architectural elements and geometric features of different rock units and their petrophysical properties such as porosity and permeability, which are important information for reservoir characterization. Despite the wide distribution of volcanic rocks in Mexico, their reservoir potential has been little studied in the past. In the Valley of Mexico, situated $4000 \mathrm{~m}$ above the Neogene volcanic rocks, groundwater is a matter of major importance as more than 20 million people and $42 \%$ of the industrial capacity of the Mexican nation depend on it for most of their water supply. Here, we present porosity and permeability data of 108 rock samples representing five different lithofacies types of the Miocene Tepoztlán Formation.. This $800 \mathrm{~m}$ thick formation mainly consists of pyroclastic rocks, mass flow and fluvial deposits and is part of the southern Transmexican Volcanic Belt, cropping out south of the Valley of Mexico and within the two states of Morelos and Mexico State. Porosities range from 1.4\% to 56.7\%; average porosity is $24.8 \%$. Generally, permeabilities are low to median $(0.2-933.3 \mathrm{mD})$ with an average permeability of $88.5 \mathrm{mD}$. The lavas are characterized by the highest porosity values followed by tuffs, conglomerates, sandstones and tuffaceous breccias. On the contrary, the highest permeabilities can be found in the conglomerates, followed by tuffs, tuffaceous breccias, sandstones and lavas. The knowledge of these petrophysical rock properties provides important information on the reservoir potential of volcanic settings to be integrated to 3D subsurface models.
\end{abstract}

Keywords: Valley of Mexico, porosity, permeability, reservoir potential, volcanic, Miocene 


\section{Introduction}

The knowledge of the petrophysical properties (e.g. porosity and permeability) of a rock unit is important for assessing its reservoir potential, not only for the oil- and gas industry but also for a variety of industrial applications,. In volcanic or volcanic-derived rocks these data are used to determine (1) groundwater resources (Foster et al., 1985; Anderson, 1994; Flint and Selker, 2003), (2) oil or gas storage (Mitsuhata et al., 1999; Levin, 1995; Hinterwimmer, 2002), (3) geothermal reservoirs (Stimac et al., 2004; Arellano et al., 2005, Carranza et al., 2008), and (4) potential environmental impacts associated with waste disposal (Neretnieks, 1980; Neeper and Gilkeson, 1996). Volcaniclastic deposits are widespread in many convergent margin and rift basin settings that have hydrocarbon production or potential, but have traditionally been regarded as poor targets for exploration (Manville et al., 2009). The high heterogeneity of volcanic reservoirs compared to clastic or carbonate reservoirs (Tang 2006) marks them as secondary reservoir targets for oil and gas exploration (Sruoga et al., 2004). However, improvements in our understanding of volcaniclastic deposits' composition, geometry, facies and distribution (Mathisen and McPherson, 1991) are now rendering them more valuable. Volcanic rock reservoirs have been reported in many locations around the world, e.g. California (Nakata, 1980), Argentina (Sruoga et al., 2004), Russia (Levin, 1995), Japan (Shimazu, 1985; Sakata et al., 1989; Mitsuhata et al., 1999), Indonesia (Sembodo, 1973) and especially China (Wang et al., 1997; Chen et al., 1999; Jinglan et al., 1999; Luo et al., 1999, 2005; Guo, 2001; Wang et al., 2003a-c; Wang et al., 2008; Feng, 2008), demonstrating the high potential for hydrocarbon exploration in volcanic and associated sedimentary rocks (Feng, 2006). A statistical analysis of the known volcanic gas reservoirs around the world was done by Zhang and $\mathrm{Wu}$ (1994; Tab. 1) and Wang et al. (1997) but so far is only available in Chinese. These studies indicate that the volcanic gas reservoirs are generally small and mainly of Tertiary and Late Cretaceous age, with burial depth in the range of 400-2000 m (Feng, 2008).

The volcanic-volcaniclastic-epiclastic terminology used in this paper largely follows that of Fisher (1961), Cas and Wright (1987), McPhie et al. (1993), and White and Houghton 
(2006). Primary volcaniclastic rocks comprise the entire range of fragmental products deposited directly by explosive or effusive eruption, regardless of whether their transport occurs through air, water, granular debris, or a combination thereof (McPhie et al., 1993; White and Houghton, 2006). This includes all sediments or rocks of pyroclastic, autoclastic, hyaloclastic or peperitic origin (White and Houghton, 2006). All reworked units are considered as secondary volcaniclastic sediments. The term epiclastic sediments may be restricted to fragments derived by weathering and erosion of pre-existing rocks, and excludes reworking of particles from non-welded or unconsolidated materials (e.g. Cas and Wright, 1987; Manville et al., 2009). According to Fisher (1961), these deposits are formed following weathering of volcanic (including volcaniclastic) rocks to produce new particles different in size and shape from the original volcaniclastic particles. Epiclastic sediments such as normal streamflow deposits thus receive a sedimentary name, e.g. sandstone. Lithofacies names are assigned on the basis of rock type, sedimentary and volcanic structures or textures, and grain size, and inferred volcanic and sedimentary eruptive and depositional processes.

Volcaniclastic sediments typically undergo rapid early diagenesis at shallow depths and low temperatures because of the abundance of unstable glass and mineral grains. Although this can destroy primary porosity through compaction and cementation, later diagenesis can create secondary porosity through dissolution (Mathisen and McPherson, 1991). Thus, the ability of volcaniclastic deposits to serve as hydrocarbon traps depends on the coincidence of porosity preservation and generation processes with the time of hydrocarbon migration (Mathisen and McPherson, 1991). Furthermore, the geometry of a volcaniclastic unit is a significant control on the reservoir potential. Burial of conical volcanic edifices and their flanking volcaniclastic aprons by fine-grained sediments such as lacustrine (Breitkreuz, 1991) or marine sediments (Yagi et al., 2009) can produce an efficient stratigraphic trap.

Especially in areas with scarce water resources such as the southwestern United States, groundwater hydrologists have considered the widespread fractured volcanic rocks as potential aquifers (Smyth and Sharp, 2006). For instance, the Tertiary felsic volcanic rocks of Nevada have been identified as important groundwater-bearing units (Winograd and Thordarson, 1975; Peterman et al., 1992; Fridrich et al., 1994; Stetzenbach et al., 
2001). In France, the water-catchments of the valley of Vourzac (Haute-Loire) are of prime importance for the supply of drinking water to the town of Le Puy-en-Velay. These are situated mainly in phreatomagmatic tuff rings and are remarkable by the total rate of groundwater flow of 80-100 1/s (Boivin and Livet, 2001). Furthermore, the volcanic rocks of central Italy often serve as efficient aquifers (Carapezza, 2003; Vinciguerra et al., 2009).

Despite the wide distribution of volcanic rocks in Mexico, their reservoir potential for oil and gas, and groundwater resources, respectively, have been little studied in the past. In the Valley of Mexico, Neogene volcanic rocks reach up to $4000 \mathrm{~m}$ thickness on top of the basement (Marsal and Graue, 1969). Here, groundwater is a matter of major importance because some 20 million people and $42 \%$ of the industrial capacity of the Mexican nation depend on it for most of their water supply (Durazo and Farvolden, 1989). Mexico City is one of the largest conurbations in the world and growing at around 2\% per year. About $70 \%$ of its total water supply, amounting to an estimated $60 \mathrm{~m}^{3} / \mathrm{s}$, is obtained from groundwater (Ortega and Farvolden, 1989; Edmunds et al., 2002) mainly produced from volcaniclastic and fractured volcanic units. A reasonable amount of data is available only on the hydraulic properties of the Pliocene-Quaternary and Quaternary-Recent deposits. The properties of the deeper aquifer units, however, are not known (Edmunds et al., 2002). However, several hundreds of litres of water per second that are continuously extracted from the Mid Tertiary volcanics for the dewatering of a mine (Carrillo-Rivera et al., 1999) in a mine district in the northern part of the Basin of Mexico, in Pachuca, Hidalgo State, are evidence for an effective reservoir and aquifer.

Due to the lack of detailed well logs of this area, a pilot study was initiated on the Lower Miocene Tepoztlán Formation, which is supposed to be linked to the processes forming the Valley of Mexico (Ferrari et al., 2003). Furthermore, the Tepoztlán Formation shows excellent exposures of its volcanic rocks, enabling an outcrop analogue study of a potential reservoir. Recently, the Tepoztlán Formation rocks have been studied in detail, with a fairly complete geologic and chemical history already established (Lenhardt, 2009; Lenhardt et al., 2010; Lenhardt et al., in press).

The aim of this study is to highlight the reservoir potential of volcanic settings and their different rock types in general and to describe the processes modifying the porosity and 
permeability of volcanic rocks after emplacement by means of petrographical and petrophysical methods. Furthermore, the results of the outcrop analogue study on the Tepoztlán Formation provide important information on the reservoir potential of the corresponding subsurface volcanic rocks of the Valley of Mexico and thus build a database to be integrated in 3D models.

Table 1. Distribution and main characteristics of volcanic oil-gas pools worldwide (translated and modified from Zhang and $\mathrm{Wu}, 1994$ )

\begin{tabular}{|c|c|c|c|c|c|c|}
\hline Countries & Age & Rock type & $\begin{array}{c}\text { Depth } \\
{[\mathrm{m}]}\end{array}$ & $\begin{array}{c}\text { Reservoir } \\
\text { thickness } \\
{[\mathrm{m}]}\end{array}$ & $\begin{array}{c}\text { Porosity } \\
{[\%]}\end{array}$ & $\begin{array}{c}\text { Permeability } \\
{[\mathrm{mD}]}\end{array}$ \\
\hline \multirow{6}{*}{ Japan } & Neogene & $\begin{array}{l}\text { Plagiorhyiolite } \\
\text { breccia }\end{array}$ & $\begin{array}{l}1515- \\
1695 \\
\end{array}$ & 100 & $20-25$ & $10-42$ \\
\hline & Neogene & Dacite lava & $\begin{array}{l}1570- \\
2020\end{array}$ & 100 & $20-25$ & $10-42$ \\
\hline & Neogene & $\begin{array}{l}\text { Andesite- } \\
\text { agglomerate }\end{array}$ & $\begin{array}{l}2180- \\
2370\end{array}$ & 57 & $15-18$ & - \\
\hline & Neogene & $\begin{array}{l}\text { Plagiorhyolite } \\
\text { lava, tuff breccia }\end{array}$ & $\begin{array}{l}2310- \\
2720\end{array}$ & 111 & $9-32$ & 150 \\
\hline & Neogene & $\begin{array}{l}\text { Andesite } \\
\text { agglomerate }\end{array}$ & $750-1200$ & 139 & $17-25$ & 1 \\
\hline & Neogene & Rhyolite breccia & & $\begin{array}{l}\text { several } \\
\text { hundred }\end{array}$ & $10-20$ & $1-20$ \\
\hline Indonesia & $\begin{array}{l}\text { Lower } \\
\text { Tertiary }\end{array}$ & $\begin{array}{l}\text { Andesite tuff } \\
\text { breccia }\end{array}$ & 2000 & $15-60$ & $6-10$ & $\begin{array}{l}\text { controlled by } \\
\text { fissures }\end{array}$ \\
\hline \multirow{3}{*}{ Cuba } & Cretaceous & Tuff & $330-390$ & - & - & - \\
\hline & Cretaceous & Tuff & $800-1100$ & 100 & - & - \\
\hline & Cretaceous & Volcanic breccia & $800-950$ & 150 & - & - \\
\hline Mexico & $\begin{array}{l}\text { Lower } \\
\text { Tertiary }\end{array}$ & Gabbro & - & - & - & - \\
\hline \multirow{3}{*}{ Argentina } & $\begin{array}{l}\text { Cretaceous- } \\
\text { Tertiary }\end{array}$ & $\begin{array}{l}\text { Andesite - } \\
\text { andesite breccia }\end{array}$ & $120-600$ & 75 & - & - \\
\hline & $\begin{array}{l}\text { Cretaceous- } \\
\text { Tertiary }\end{array}$ & Tuff & 2100 & - & 20 & - \\
\hline & Tertiary & $\begin{array}{l}\text { Rhyolite, } \\
\text { andesite }\end{array}$ & - & - & - & - \\
\hline \multirow{5}{*}{ USA } & Cretaceous & Serpentinite & $330-420$ & $\begin{array}{l}\text { average } \\
4.5\end{array}$ & - & - \\
\hline & Cretaceous & Serpentinite & $400-500$ & $\begin{array}{l}\text { average } \\
4.5\end{array}$ & - & - \\
\hline & Cretaceous & Olivine basalt & - & - & - & - \\
\hline & Tertiary & Trachyte & $850-1350$ & $18-49$ & $5-17$ & $0.01-25$ \\
\hline & Tertiary & Tuff & 2000 & - & - & - \\
\hline \multirow{3}{*}{ Russia } & Tertiary & Tuff & $\begin{array}{l}2500- \\
2700\end{array}$ & - & $0.1-14$ & $0.1-0.01$ \\
\hline & $\begin{array}{l}\text { Cretaceous- } \\
\text { Tertiary }\end{array}$ & $\begin{array}{l}\text { Tuff breccia, } \\
\text { andesite }\end{array}$ & $\begin{array}{l}2950- \\
4900 \\
\end{array}$ & 100 & $\begin{array}{l}\text { average } \\
20.2\end{array}$ & $0-2.3$ \\
\hline & Upper & Andesite-dacite & 1580 & $300-500$ & $6-13$ & $0.01-3$ \\
\hline
\end{tabular}




\begin{tabular}{|l|l|l|l|l|l|l|}
\hline & Tertiary & tuff & & & & \\
\hline Ghana & Quaternary & Breccia & 500 & 125 & $15-21$ & - \\
\hline
\end{tabular}

-, no data available

\section{Geological setting}

The Valley of Mexico refers to the lower part of the Basin of Mexico (Fig. 1). The Basin of Mexico is one of the largest of a series of closed catchments located in the Transmexican Volcanic Belt (Vázquez-Sánchez and Jaimes-Palomera, 1989; Mooser and Molina, 1993). It is a closed basin located on a graben structure, which developed during the Oligocene, characterized by a thick sequence of volcanic and lacustrine deposits (Edmunds et al., 2002). In those times the basin drained to the south. The runoff outlet was closed during the Pleistocene as the result of a series of volcanic activities (De Cserna et al., 1987) that formed the Sierra de Chichinautzin to the south of the basin (Edmunds et al., 2002). The floor of the Valley of Mexico has an elevation of about 2236 $\mathrm{m}$ above sea level (asl) and the lowest part is still occupied by what remains of Lake Texcoco. The drainage divides in the mountains that surround the Valley are frequently more than $3000 \mathrm{~m}$ asl, and the lowest pass across the divide is about $2260 \mathrm{~m}$ asl (Durazo and Farvolden, 1989). Groundwater recharge occurs in the volcanic rocks of the mountains that surround the Valley to form the Basin of Mexico (Durazo and Farvolden, 1989). Seismic studies and deep wells (drilled by PEMEX, Petróleos Mexicanos) in the Basin of Mexico reaching $4000 \mathrm{~m}$, give evidence that the volcaniclastic succession in the lower unit of the basin is correlative with the Miocene Tepoztlán Formation (Ferrari et al., 2003) (Fig. 2). The time of the deposition of the Tepoztlán Formation is likely concurrent with the main phase of formation of the basin.

The Tepoztlán Formation crops out in an area of approximately $180 \mathrm{~km}^{2}$ and has an overall maximum thickness of ca. $800 \mathrm{~m}$. The volume of the deposited material, still remaining after erosion, was calculated with the help of a Geographic Information System (GIS) as $130 \mathrm{~km}^{3}$ (Lenhardt et al., 2010). The formation is widespread around the villages of Malinalco and Chalma in Mexico State and Tepoztlán and Tlayacapan in Morelos State; sparse outcrops are located east of Tlayacapan and southeast of the Nevado de Toluca (Capra and Macías, 2000; García-Palomo et al., 2002). 
A variety of Eocene-Oligocene (Balsas Group) and older rocks, mostly Cretaceous limestones, underlie the formation. They are covered by lava flows of Pliocene to Holocene age. Close to Malinalco, the Tepoztlán Formation crops out between the San Nicolás Basaltic Andesite and the overlying Basal Mafic Sequence (García-Palomo et al., 2000). In Tepoztlán and the eastern vicinities it unconformably overlies the Balsas Group and is covered by the Chichinautzin Formation.

The formation is composed of calc-alkaline volcanic and volcaniclastic rocks. The volcanic rocks have predominantly andesitic to dacitic compositions; however, rhyolites are also present (Lenhardt, 2009). The entire succession comprises pyroclastic deposits (fall, surge and flow deposits), deposits from lahars (debris-flow and hyperconcentratedflow deposits) and coarse- to fine-grained fluvial and lacustrine deposits (conglomerates, sandstones and mudstones). Few lava flows and dykes are present.

Bedding within the Tepoztlán Formation is generally flat-lying or gently dipping with up to $10^{\circ}$ to N/ NNE. The succession is disrupted by normal faults and dykes. Displacements at faults are frequently about half a meter and rarely exceed a few meters.

Magnetostratigraphy combined with K/Ar and Ar/Ar geochronology revealed an Early Miocene age (22.75-18.78 Ma; Lenhardt et al., 2010).

Sedimentological studies on the Tepoztlán Formation at different scales show a very complex interaction of fluvial, eruptive and gravitational processes in time and space (Lenhardt, 2009; Lenhardt et al., 2010), and thus provide evidence of the complex facies architecture, reflecting alternating periods of high-volume deposition in response to eruptive activity, and low-volume deposition in inter-eruption intervals (Lenhardt et al., in press). The spatio-temporal architectural elements of the Tepoztlán Formation reveal a dominant apron facies association, which is characterized by debris-flow and hyperconcentrated-flow deposits, up to $40 \mathrm{~m}$-thick pyroclastic flow deposits, coarsegrained pyroclastic fall deposits, and coarse-grained fluvial conglomerates. A secondary distal facies association is characterized by the dominating deposition of sandstones and conglomerates, resulting from sheet floods and fluvial sediments in a braided river system. Especially the wedge-shaped aprons of volcaniclastic material near former volcanic vents and major fault zones where several units of permeable material are 
connected with each other are seen to feature a high reservoir potential (Breitkreuz, 1991).

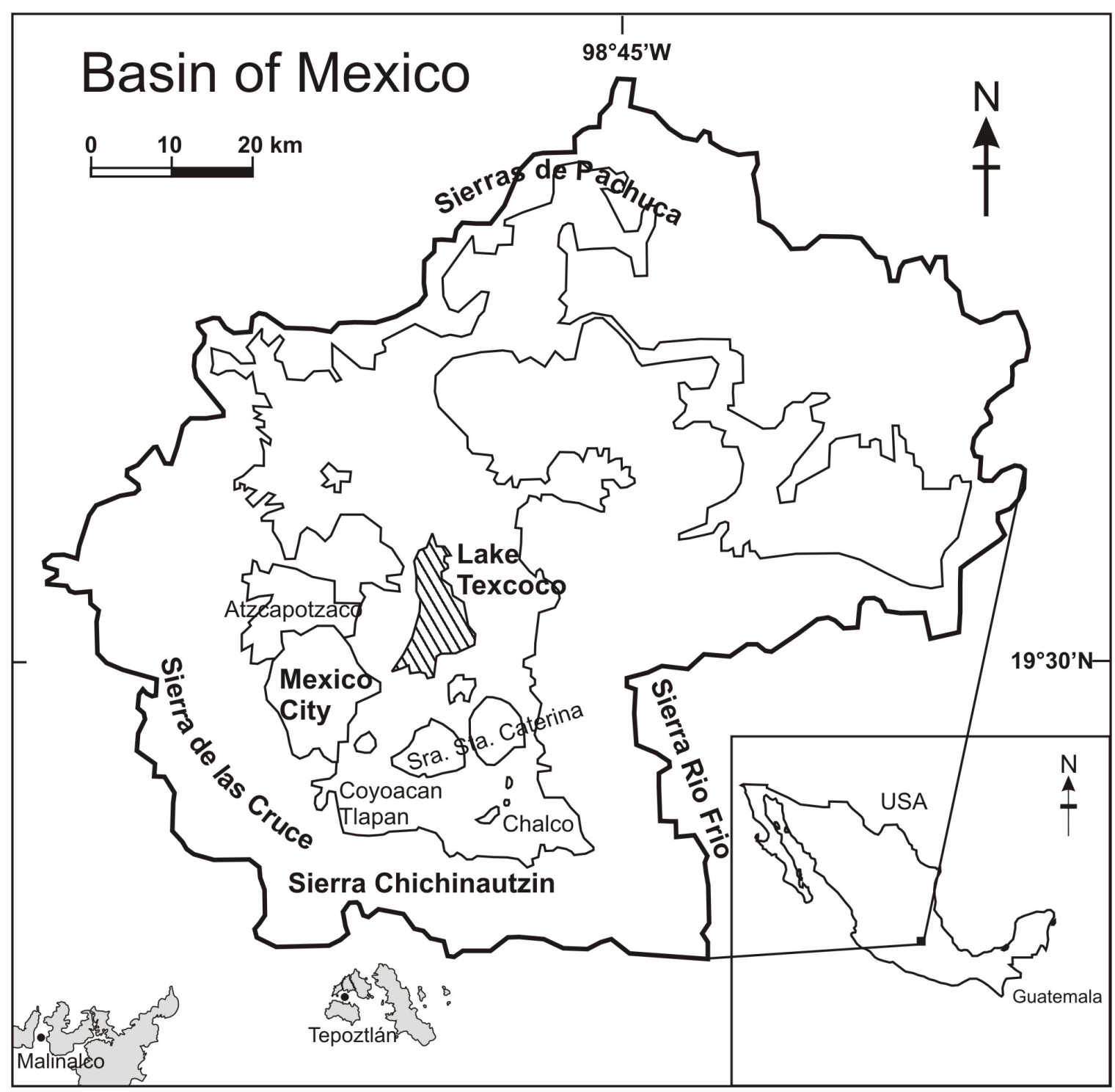

Figure 1. Location map of the Basin of Mexico and areas south of the basin exposing the Tepoztlán Formation (shaded in grey) (after Edmunds et al., 2002). 


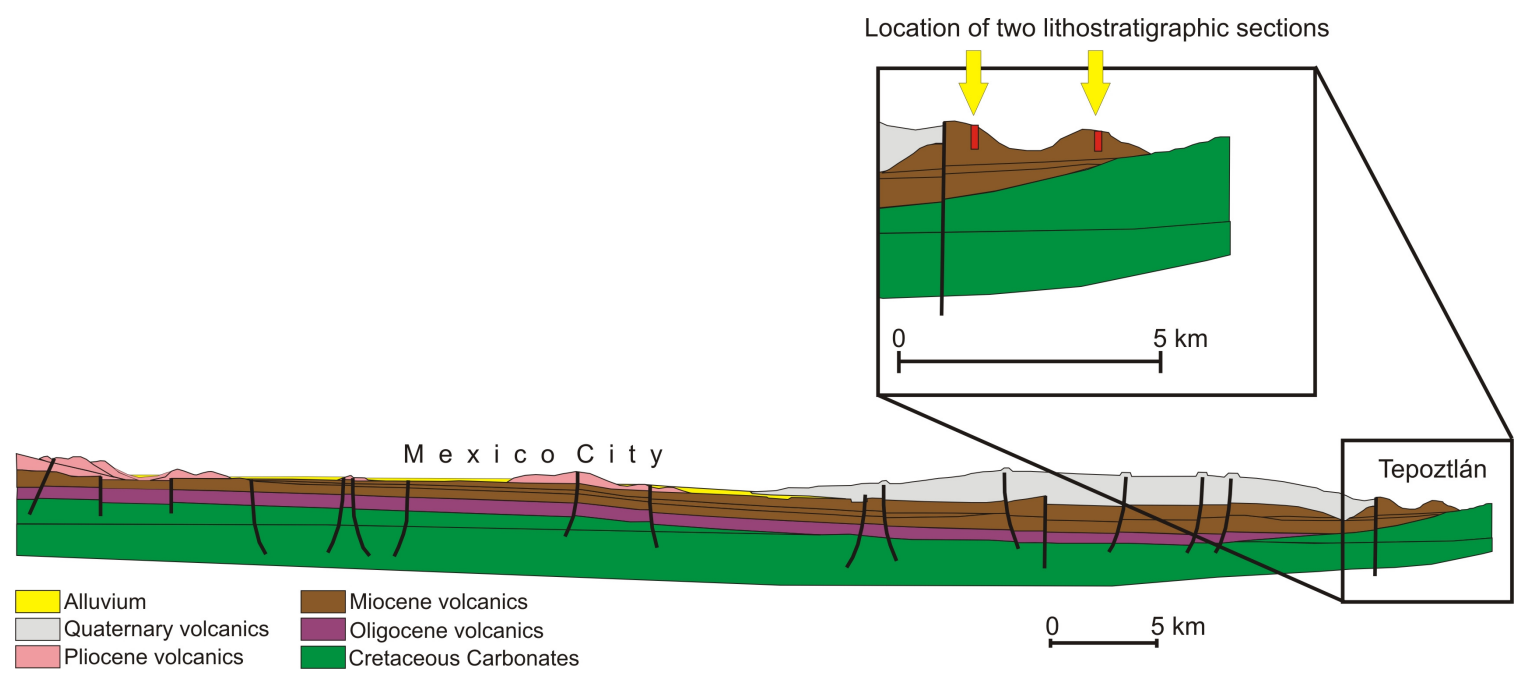

Figure 2. Cross-section through the Valley of Mexico (after Mooser et al., 1996) with the outcrops of the Tepoztlán Formation and the locations of two sampled lithostratigraphic sections in the far south.

\section{Materials and methods}

This study is based on porosity and permeability measurements of 108 representative samples from five different lithofacies types (5 lavas, 67 tuffs, 5 tuffaceous breccias, 11 conglomerates, 20 sandstones) identified in the Tepoztlán Formation and sampled from several lithostratigraphic sections (Lenhardt, 2009). Core samples with diameters of $5 \mathrm{~cm}$ were obtained by using a gasoline-driven drilling machine with diamond-studded drill heads. Core descriptions were prepared, detailing lithology and alteration. Furthermore, the degree of welding was described for tuff samples. The nature and intensity of pore space and fractures was assessed through thin-section studies of resin-impregnated samples from selected core-plugs. Measurements of skeletal density (helium pycnometer AccuPyc 1330) and envelope density (DryFlo pycnometer GeoPyc 1360) allowed the calculation of porosity. A gas mini-permeameter was used for permeability measurements utilizing pressured differential air flow through a plug sample. Permeability was calculated by incorporating the injection pressure $p_{i}$, the mass flow rate $M_{i}$ and the ambient atmospheric pressure $p_{a}$ (Fig. 3). All measurements were conducted on oven dried samples. 


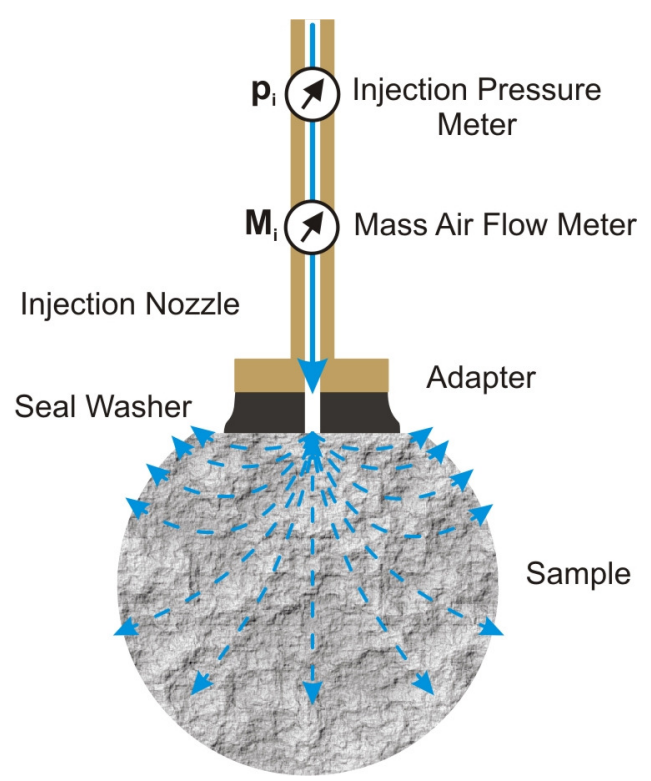

Figure 3. Scheme of the gas pressure permeability measurement. The permeameter utilizes pressured differential air flow through a plug sample. Permeability is calculated by incorporating the injection pressure $p_{i}$, the mass flow rate $M_{i}$ and the ambient atmospheric pressure $p_{a}$ (cf. Goggin et al., 1988).

\section{Results}

\section{Lithology and petrography}

The studied samples of the Tepoztlán Formation comprise of 5 volcanic and sedimentary lithofacies types distinguished on the basis of rock type, sedimentary and volcanic structures or textures, and grain size and consist of lava, tuff, tuffaceous breccia, sandstone and conglomerate (c.f., Lenhardt et al., in press).

\section{Lava}

The 15-25 m-thick flows within the Tepoztlán Formation commonly have a blocky carapace and a dense core, and exhibit an irregular, unconformable contact to the underlying deposits. Angular fragments of the carapace range from $3-50 \mathrm{~cm}$ in size at the base or the top of massive flows. All flows have a porphyritic to glomeroporphyritic 
texture. Plagioclase is the most abundant phase with subordinate K-feldspar, clinopyroxene and amphibole. Accessory phases consist of mica, abundant titanomagnetite and other accessories (Lenhardt et al., 2010). The groundmass shows a hyalophylitic, sometimes trachytic texture, comprised of plagioclase microlites and an ore phase (titanomagnetite). The whole rock $\mathrm{SiO}_{2}$ content of the lavas ranges from 55.9 to $60.6 \mathrm{wt} . \%$, identifying them as andesites or dacites (Lenhardt, 2009).

The volcanic facies, represented by andesites and dacites are interpreted as viscous, slow moving blocky lava flows (MacDonald, 1972; Mueller, 1991) as they are associated with lava domes and coulées (Williams and McBirney, 1979; Orton, 1996). The massive to brecciated units display the attributes of a coherent flow in which autobrecciation processes were prevalent and produced breccia during flow advance (Bonnichsen and Kauffmann, 1987).

\section{Tuff}

The massive pumice-rich tuffs exhibit of accessory and minor accidental lithic fragments (up to $10 \mathrm{~cm}$ in diameter) in a matrix of bubble wall shards and phenocrysts (feldspars, augite, rare quartz). Accessory lithic clasts are comprised of gray to red porphyritic rocks of dacitic to andesitic composition (58.5 - 66.5 vol.\% $\mathrm{SiO}_{2}$; Lenhardt, 2009). Pumice clasts range from creamy white to pale yellow in color. They are relatively dense to finely vesicular and usually porphyritic, containing predominantly augite and plagioclase as phenocrysts. Within the matrix, pumice clasts usually do not exceed diameters of $6 \mathrm{~mm}$. However, in pumice concentration zones on top of single units, clasts can reach up to 10 $\mathrm{cm}$ in diameter. Due to transportation and abrasion they appear subrounded to rounded. The deposits usually show a normal coarse-tail grading of the lithic clasts while the pumice clasts show a reverse grading. Thicknesses of single units can vary from 0.1 to $9.0 \mathrm{~m}$ with an average of $1.5 \mathrm{~m}$. The deposits partly drape the pre-eruption topography, thickening in valleys and depressions. Their lower bounding surfaces are flat or reflect the paleosurface, their tops are mostly eroded. The deposits occur as single units or as a series of stacked beds.

The colour of the tuff samples, varying from creamy beige to reddish purple, reflects the changes in the degree of welding and alteration. Welding of pyroclastic deposits involves 
flattening of glass shards under compactional load at temperatures above the glass transition temperature. Progressive welding is recorded by changes in the petrographic (e.g. fabric) and physical (e.g. density, porosity) properties of the deposits (Quane and Russel, 2005). So as welding intensifies, the primary porosity is reduced whereas the density increases (Ragan and Sheridan, 1972; Streck and Grunder, 1995; Rust and Russel, 2000). The welding range is subdivided into four facies of welding (Tab. 2): 1) incipiently welded (e.g., Peterson, 1979; Streck and Grunder, 1995) or rank II of welding according the scheme of Quane and Russel (2005), 2) partially welded (Smith, 1960) or rank III after Quane and Russel (2005), 3) moderately welded (Wilson and Hildreth, 2003) or rank IV after Quane and Russel (2005), and 4) densely welded (Smith, 1960; Sheridan and Ragan 1976; Peterson 1979; Wilson and Hildreth, 2003) or rank V after Quane and Russel (2005). The principal hydrothermal minerals in the samples include silica polymorphs, montmorillonite, and hematite. Most of the hydrothermal alteration in the welded tuff occurs as fracture and cavity fillings.

This lithofacies is interpreted as ash-flow deposit and is described by many authors as the most common ignimbrite lithofacies (e.g. Ross and Smith, 1961; Sparks, 1976; Wilson and Walker, 1982; Branney and Kokelaar, 2002).

\section{Tuffaceous breccia}

This lithofacies is composed of angular to subangular clasts in a pinkish red matrix of fine to medium sand. They occur in laterally extensive (up to several 100 meters) sheets with planar bases and eroded tops. Average thicknesses of single units are about $4 \mathrm{~m}$; however, vertical amalgamation surfaces between stacked units are rarely visible, resulting in deposits up to $14 \mathrm{~m}$ thick without any visible bounding surfaces. The deposits show no signs of grading or sorting. The clast size usually is in the range of pebbles and cobbles, not exceeding diameters of $20 \mathrm{~cm}$; however, single outsized clasts of $2 \mathrm{~m}$ in diameter have been observed. The matrix of the deposits is commonly composed of lithic and pumice fragments, crystals and glass shards, showing significant alteration to clay minerals. The fragments do not show any alignment within the matrix. 
The poor sorting and massive appearance are evidence for transport and deposition of this lithofacies by and from debris flows (Hampton, 1975; Johnson and Rodine, 1984; Smith and Lowe, 1991; Coussot and Meunier, 1996; Pierson et al., 1996).

\section{Conglomerate}

This lithofacies is poorly sorted with a grain-size distribution from fine sand to cobbles. Gravel particles, representing the main grain-size are subangular to subrounded. The coarsest cobbles and boulders are usually up to $20 \mathrm{~cm}$ across. Locally, lenses of crossstratified sandstone occur. The matrix dominantly consists of sand grains, resembling small clasts of lava, pumice or ash particles. The conglomerates form single beds or sets of stacked beds. Individual beds can be separated by thin sandy layers. Thicknesses vary from 0.2 to $6 \mathrm{~m}$ with an average of $1 \mathrm{~m}$. The conglomerates show flat or concave lower bounding surfaces, pinching out laterally. Lenticular strata are bounded by scour surfaces. Laterally, extensions range from few meters up to several tens of meters. Preferred clast orientation occurs parallel to bedding in cross-stratified units.

This lithofacies is very common in gravel-bedload stream deposits (e.g. Steel and Thompson, 1983; Smith, 1990; Siegenthaler and Huggenberger, 1993) as they appear in sheets and lenses as manifested in gravel bars in braided river systems (e.g. Miall, 1977).

\section{Sandstone}

This lithofacies consists of gray tuffaceous sandstones, comprising glassy material, small lava and pumice particles and minor rounded phenocrysts, dominated by feldspars and pyroxenes. Trough cross-bedding is the dominant sedimentary structure. However, planar cross-bedding or scour-fill bedding is also common. Individual units are stacked, often forming multilateral and single- or multistorey packages. The thicknesses of the units range from 0.1 to $6 \mathrm{~m}$ with an average of $0.8 \mathrm{~m}$. The lateral extent cannot be determined clearly in all cases; however, some outcrops show extents of up to $150 \mathrm{~m}$. They are characterized by erosive, concave-up to flat bases. Laterally, individual elements pinch out or are completely eroded away. Subangular to subrounded, pebble- to cobble-sized clasts (up to $20 \mathrm{~cm}$ ) are concentrated on erosional contacts. Fining-upward successions are common, often with clayey ripple cross-laminated layers on top. 
Based on the composition, the presence of crystals and the absence of basement material, the original fragmentation process and components support an initial pyroclastic origin. However, the sedimentary structures indicate significant reworking of either primary pyroclastic material or material that had already previously been reworked by lahars. Cross-stratification with unimodal paleocurrent pattern, fining-upward sequences, and channel scours at the base are all consistent with fluvial channel fill (Miall, 1978; Walker and Cant, 1984). Trough cross-stratification indicates infilling of a channel by bedload in the form of migrating bedforms (Miall, 1977; Harms et al., 1982; Siegenthaler and Huggenberger, 1993; Kataoka, 2005). Planar-cross bedded sediments are typically interpreted as the deposits of migrating straight-crested dunes, generally formed within the deeper portion of the active channel (Miall, 1985), or by avalanching on the slipfaces of simple bars (Miall, 1996). Such bars may have either been bank-attached (lateral bars) or detached as transverse or medial bars (Todd, 1996). Thus, the deposits of this facies are interpreted as channel fill in a braided river. Fining-upward sequences resulted from the lateral migration of streams or a deceleration in flow velocity due to a decrease in channel activity. Multistoried fining-upward packages with erosional bases suggest frequent channel reactivation with development of bars in fluvial systems. Pebble- to cobble-sized clasts on erosional surfaces were deposited as a lag deposit on a channel floor. Clast abrasion in streams was rather inefficient as shown by the subangular to subrounded shapes, which is why it is supposed that all clasts were deposited at a proximal to median distance from the source area. The fine, clayey layers on top of this lithofacies points to very low flow energies after relocation of the main channel.

Table 2: Petrographic characteristics used to define ranks of welding

\begin{tabular}{|l|l|l|}
\hline Rank & Ash matrix & Pumice lapilli \\
\hline $\begin{array}{l}\text { Incipiently welded } \\
\text { rank } \text { II }^{2}\end{array}$ & $\begin{array}{l}\text { } \text { or } \\
\text { between shards, no coalescence } \\
\text { of glassy material }\end{array}$ & $\begin{array}{l}\text { Randomly oriented, no } \\
\text { deformation, no eutaxic texture, } \\
\text { fracture takes place around rather } \\
\text { than through pumice }\end{array}$ \\
\hline Partially welded $^{3}$ or rank III & $\begin{array}{l}\text { Highly porous, originally } \\
\text { spherical bubble shards slightly } \\
\text { ellipsoidal, some coalescence of } \\
\text { glassy material }\end{array}$ & $\begin{array}{l}\text { Slightly flattened; fracture takes } \\
\text { place through rather than around } \\
\text { pumice }\end{array}$ \\
\hline $\begin{array}{l}\text { Moderately welded } \\
\text { rank } \text { IV }^{2}\end{array}$ & $\begin{array}{l}\text { Relatively soft, moderately } \\
\text { foliated but individual shards } \\
\text { only slightly deformed, clasts are }\end{array}$ & $\begin{array}{l}\text { Foliated into eutaxic texture with } \\
\text { both moderately deformed } \\
\text { pumice and fully collapsed }\end{array}$ \\
\hline
\end{tabular}




\begin{tabular}{|l|l|l|}
\hline & $\begin{array}{l}\text { moderately adhered to one } \\
\text { another }\end{array}$ & fiamme present \\
\hline Densely welded $^{5}$ or rank $\mathrm{V}^{2}$ & $\begin{array}{l}\text { Shards strongly foliated, strongly } \\
\text { adhered to one another and } \\
\text { moderately deformed }\end{array}$ & $\begin{array}{l}\text { Foliated into strong eutaxic } \\
\text { texture, collapsed to fiamme that } \\
\text { are obsidian-like }\end{array}$ \\
\hline
\end{tabular}

${ }^{1}$ Peterson (1979), Streck and Grunder (1995); ${ }^{2}$ Quane and Russel (2005); ${ }^{3}$ Smith (1960);

${ }^{4}$ Wilson and Hildreth (2003); ${ }^{5}$ Smith (1960), Sheridan and Ragan (1976), Peterson (1979), Wilson and Hildreth (2003)

\section{Pore types and origin}

Following the description of primary and secondary porosity formation processes given in Sruoga and Rubinstein (2007), the processes documented in the rocks of the Tepoztlán Formation can be classified as follows:

i) Primary processes that are active between the pre-emplacement stage and the final cooling of volcanic rocks under closed-system conditions. Pumice-bearing pyroclastic rocks develop a protracted cooling history caused by their high heat-retention capacity. Thus, the interaction between the solid and the volatile phases is very efficient during the deuteric stage. By contrast, lavas and dense glasses are rapidly quenched, and their deuteric stage is short lived.

ii) Secondary processes that operate later in the evolution of volcanic rocks, after their complete cooling, and in open-system conditions, such as alteration, metamorphism, and tectonic deformation.

In the tuffs, the major porosity arises from pumice fragments and loose packing of vitric shards. The porosity in the tuff samples (Tab. 3) includes primary porosity (intrashard and intrapumice porosity, intracrystalline sieve or moldic porosity, vesicular porosity) and secondary porosity (fractures).

The development of intershard and intrapumice porosity (Fig. 4a) of the rock depends on vesicularity, bubble size distribution, time, pressure difference, and viscosity of the preeruptive magma. In non-welded to moderately welded tuffs the pore space corresponds to former bubbles, gas pockets, non-flattened pumice fragments and loose packing of vitric shards and crystals. 
The feldspar sieve texture (Fig. 4b), commonly observed in tuffs, is produced by dissolution of crystal phases by deuteric fluids. During the deuteric process, feldspar alteration involves an initial dissolution stage in fluids with a low $\mathrm{pH}$ and is frequently followed by precipitation of new feldspar phases (Sruoga and Rubinstein, 2007). The best time constraint for feldspar dissolution is the presence of vapour-phase crystals in relict crystal sections and the precipitation of a newly formed K-feldspar (Sruoga and Rubinstein, 2002). This sieve texture results in an intracrystalline porosity where pores are rarely connected, leading to a low permeability.

The vesicular porosity (Fig. 4c) within tuffs corresponds to former bubbles and gas pockets.

The observed microfractures within the Tepoztlán tuffs (Fig. 4d) are associated with hydrothermal and tectonic processes following their deposition. Many of the fractures originated as joints and formed during cooling of the tuff after emplacement (cf. Winograd, 1971). The fractures range from microscopic to cavernous in size and are especially important for both aquifers and petroleum reservoirs. The abundance and nature of fractures varies throughout the studied samples. They are planar to irregular in form. Their angles range from subhorizontal to vertical. Fractures are most abundant and the widest in densely welded tuff. However, these fractures are mostly filled with hydrothermal minerals and are sealed. Less abundant and smaller fractures are found in incipiently and partially welded tuff in which no filling or sealing was observed (cf. Winograd, 1971; Dobson et al., 2003).

In contrast to the tuffs, the pore types of the lava samples and the sandstones and conglomerates are more uniform. While in the lava samples, the entire porosity is a vesicular porosity and due to former bubbles and gas pockets (Fig. 4e), in sandstones and conglomerates, the dominating pore type is an inter-particle porosity (Fig. 4f).

Table 3. Primary and secondary processes and porosity types.

\begin{tabular}{|l|l|l|}
\hline & Processes & Porosity Types \\
\hline \multirow{4}{*}{ Primary } & Welding & $\begin{array}{l}\text { Intershard/Interparticle and } \\
\text { Intrapumice }\end{array}$ \\
\cline { 2 - 3 } & Deuteric Crystal Dissolution & Intracrystalline sieve or moldic \\
\cline { 2 - 3 } & Gas Release & Vesicular \\
\hline
\end{tabular}




\begin{tabular}{|l|l|l|l|}
\hline Secondary & Fracture & Tectonic & Tectonic Fracture \\
\hline
\end{tabular}
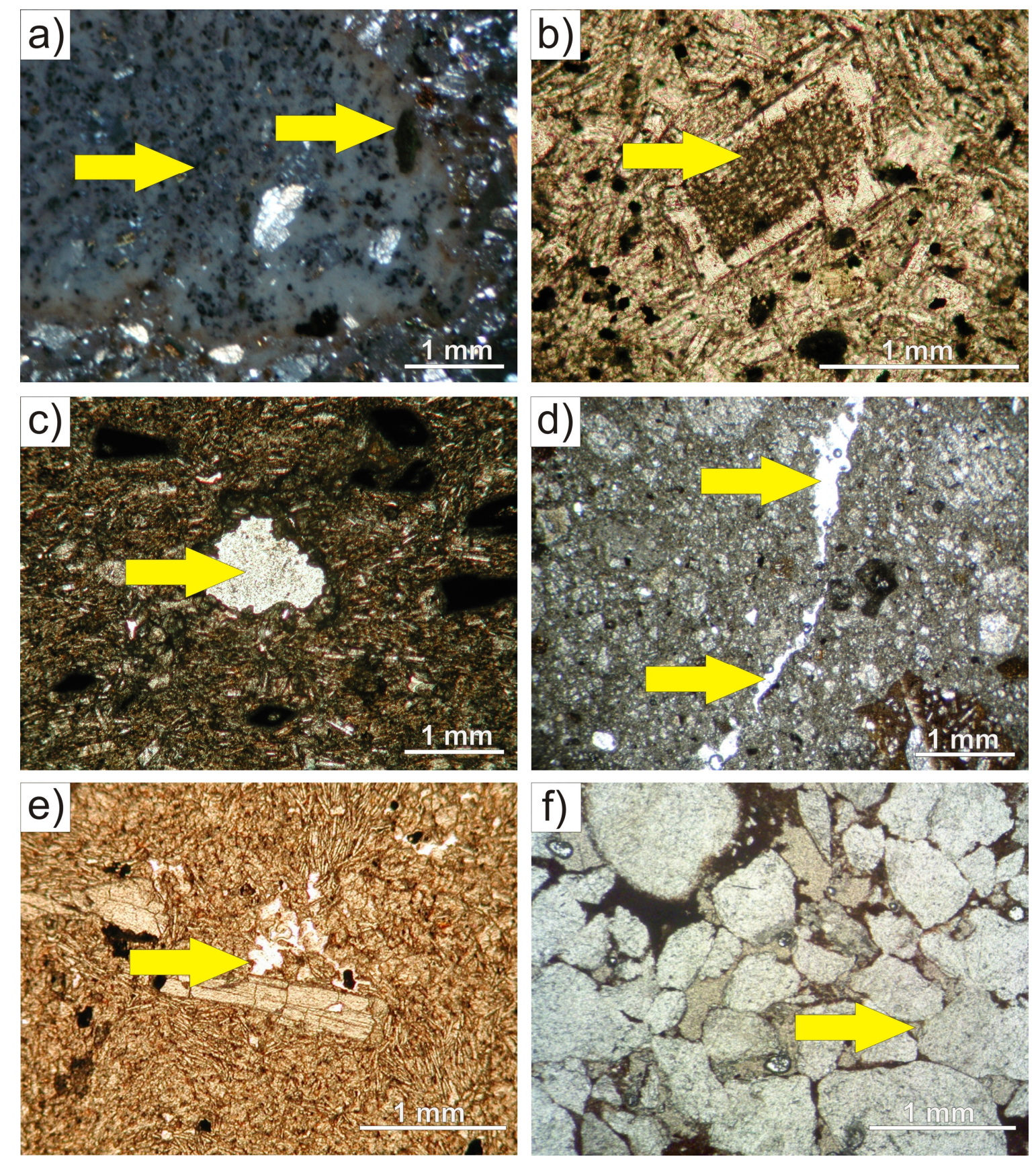

Figure 4. Photomicrographs of Tepoztlán tuffs showing the different types of porosity. a) intershard and intrapumice porosity, b) intracrystalline sieve or moldic porosity, c) vesicular porosity, d) fractures, e) vesicular porosity in lava, f) inter-particle porosity in sandstone. 


\section{Porosity and Permeability}

Here, we present porosity and permeability data of five different lithofacies types, identified in the Tepoztlán Formation (Lenhardt, 2009). Porosity is the percentage of void space in a porous medium. Variations in porosity can be correlated with lithology, degree of welding, and alteration. The lavas are characterized by the highest porosity values (mean of 30\%) followed by tuffs, (mean 25.6\%), conglomerates (mean 32.3\%), sandstones (mean 18.9\%) and the tuffaceous breccias showing the lowest porosities with mean values of $15.2 \%$ (see Tab. 4). The relatively high porosities of the lava samples can be explained by numerous vesicles and gas pockets in the lava. The tuff samples have a large range in measured porosity that corresponds to differences in welding and compaction after emplacement (Tab. 5). The welding range can be subdivided into four distinct welding facies (Fig. 5): 1) incipiently welded (> 36\%), 2) partially welded (36$30 \%), 3$ ) moderately welded (30-2\%), and 4) densely welded ( $<2 \%)$. Generally, a steady decrease in porosity can be noticed from incipiently (mean of $37.7 \%$ ) to densely welded tuffs with strongly reduced porosities (mean of $1.6 \%$ ).

Variations in permeability are also correlated with lithology, alteration, and, in case of the tuff samples, with degree of welding. The highest permeabilities within the Tepoztlán Formation rocks can be found in the conglomerates (mean $594.6 \mathrm{mD}$ ), followed by the tuffs (mean of $37 \mathrm{mD}$ ), tuffaceous breccias (mean $22.1 \mathrm{mD}$ ), sandstones (mean $21.1 \mathrm{mD}$ ) and lavas exhibiting the lowest mean values of $1.2 \mathrm{mD}$ (Tab. 4).

Comparable with the porosity values and corresponding to differences in welding and compaction, a general decrease in mean permeability values can be seen in tuffs from 5.2 $\mathrm{mD}$ in incipiently welded samples to $0.3 \mathrm{mD}$ in densely welded samples. Nevertheless, an increase in permeability values can be observed in partially $(75.5 \mathrm{mD})$ and moderately welded samples $(19 \mathrm{mD})$. This large difference in matrix permeability between incipiently and densely welded tuffs is similar to that reported by several authors (Winograd, 1971; Smyth-Boulton, 1995; Dobson et al., 2003; Smyth and Sharp, 2006), reflecting the strong compaction and pore closure during the welding process. In general, rocks with permeabilities lower than $1 \mathrm{mD}$ are considered tight; higher values indicate reservoir rocks (cf., Lucia, 2007). Fig. 6 shows that most incipiently and partially welded 
tuff samples group together in the reservoir field and thus, have a relatively high reservoir potential compared to the values taken from international siliciclastic and carbonate reservoirs (Ehrenberg and Nadeau, 2005). Considering the volumetric estimate of volcaniclastics of $27 \%$ of the total volume of sedimentary rocks within the geologic record (Vincent, 2000) it seems reasonable to confer these rocks a similar importance like conventional reservoir rocks. Within the Tepoztlán Formation, the same high values can be applied to the tuffaceous breccias and sandstone samples of which the majority of the samples fit into the field of international reservoirs. The conglomerates are characterized by the best reservoir potential, which is indicated by the highest porosity and permeability values.

Table 4. Porosity and permeability data of the Tepoztlán Formation.

\begin{tabular}{|l|l|l|l|l|l|}
\hline \multicolumn{1}{|c|}{ Facies } & $\begin{array}{c}\text { Number of } \\
\text { measurements }\end{array}$ & $\begin{array}{c}\text { Range of } \\
\text { porosity }(\boldsymbol{\%})\end{array}$ & $\begin{array}{c}\text { Porosity mean } \\
(\boldsymbol{\%})\end{array}$ & $\begin{array}{c}\text { Range of } \\
\text { permeability } \\
(\mathbf{m D})\end{array}$ & $\begin{array}{c}\text { Permeability } \\
\text { mean (mD) }\end{array}$ \\
\hline Lava & 5 & $3.5-56.7$ & 30 & $0.4-1.8$ & 1.2 \\
\hline Tuff & 67 & $1.4-39.6$ & 25.6 & $0.2-211$ & 37 \\
\hline $\begin{array}{l}\text { Tuff breccia } \\
\text { (mass flow } \\
\text { deposits) }\end{array}$ & 5 & $14.2-16.4$ & 15.2 & $20.0-23.7$ & 22.1 \\
\hline Conglomerates & 11 & & & & \\
\hline Sandstones & 20 & $28.0-35.3$ & 32.3 & $269.2-933.3$ & 594.6 \\
\hline
\end{tabular}

Table 5. Porosity and permeability data of the Tepoztlán Formation tuffs.

\begin{tabular}{|l|l|l|l|l|l|l|}
\hline \multicolumn{1}{|c|}{ Facies } & $\begin{array}{c}\text { Degree of } \\
\text { welding }\end{array}$ & $\begin{array}{c}\text { Number of } \\
\text { measurements }\end{array}$ & $\begin{array}{c}\text { Range of } \\
\text { porosity } \\
(\mathbf{\%})\end{array}$ & $\begin{array}{c}\text { Range of } \\
\text { Porosity } \\
\text { mean }(\boldsymbol{\%})\end{array}$ & $\begin{array}{c}\text { permeability } \\
(\mathbf{m D})\end{array}$ & $\begin{array}{c}\text { Permeability } \\
\text { mean (mD) }\end{array}$ \\
\hline Tuff & $\begin{array}{l}\text { incipiently } \\
\text { welded }\end{array}$ & 7 & $36.2-39.6$ & 37.7 & $3.0-7.5$ & 5.2 \\
\hline Tuff & $\begin{array}{l}\text { partially } \\
\text { welded }\end{array}$ & 25 & $30.4-35.9$ & 33.0 & $0.7-211$ & 75.5 \\
\hline Tuff & $\begin{array}{l}\text { moderately } \\
\text { welded }\end{array}$ & 29 & $5.5-29.6$ & 21.3 & $0.2-80.7$ & 19.0 \\
\hline Tuff & $\begin{array}{l}\text { densely } \\
\text { welded }\end{array}$ & 6 & $1.4-1.8$ & 1.6 & $0.2-0.7$ & 0.3 \\
\hline
\end{tabular}




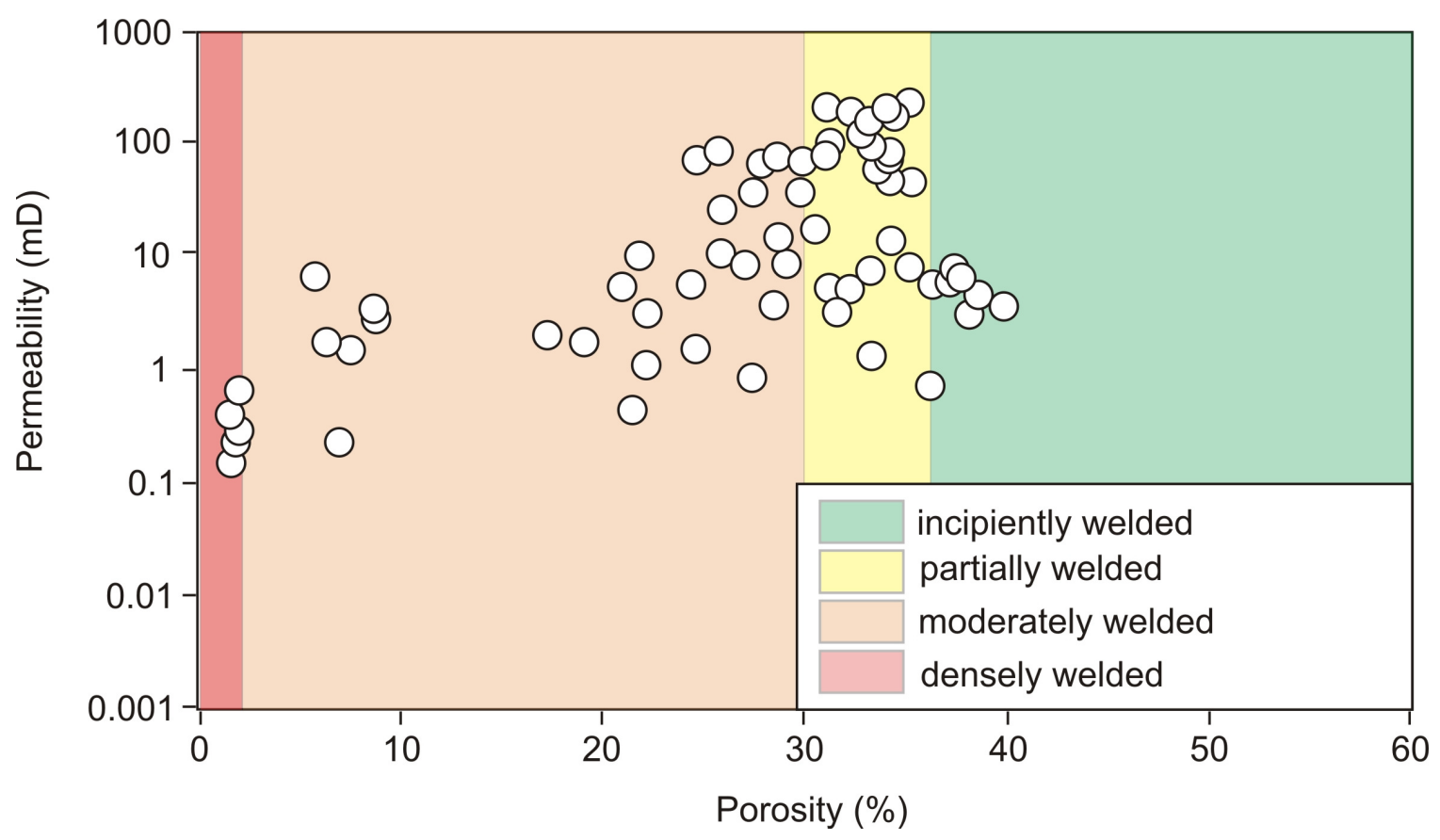

Figure 5. Correlation of porosity and permeability with the degree of welding of tuffs of the Tepoztlán Formation.

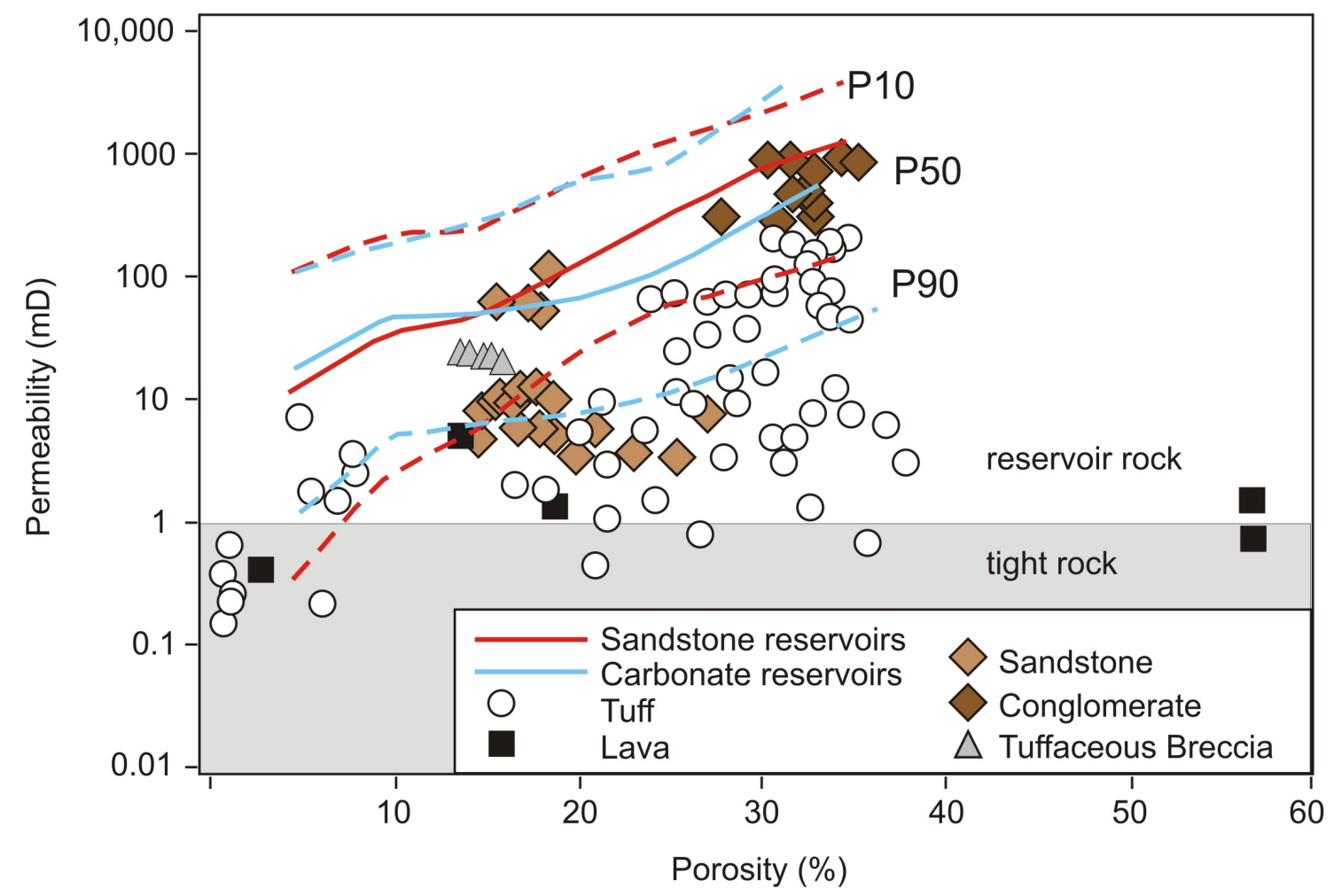

Figure 6. Correlation of porosity and permeability of the different rock types of the Tepoztlán Formation with international sandstone and carbonate reservoirs. P10: 10\% of 
international sandstone/carbonate reservoirs, P50: 50\% of international sandstone/carbonate reservoirs, P90: 90\% of international sandstone/carbonate reservoirs.

\section{Discussion}

The outcrops exposing the Tepoztlán Formation provide a representative data set for studying processes governing porosity and permeability in a volcanic setting, which have to be considered for reservoir characterization. Although texturally variable, the rocks are chemically similar, being uniformly generated by dacitic-andesitic volcanism and related sedimentation, and comprise only three major lithologies: lava, tuffs and epiclastic sediments. The tuffs can be subdivided into four categories: 1) incipiently welded, 2) partially welded, 3) moderately welded, and 4) densely welded. The welding is dependant upon compaction of the tuff components upon or soon after deposition and the temperature of particles and gases upon deposition (cf. Ross and Smith, 1961).

The results of the core description and thin section analysis show that the highest porosities and permeabilities occur in conglomerates followed by incipiently and partially welded tuffs (Fig. 6), corresponding with the hydrologic properties of known international reservoirs in clastic and carbonate reservoirs (e.g. Ehrenberg and Nadeau, 2005). Compared to other facies, the porosity in incipiently welded tuffs is highest whereas the permeability remains relatively low. In tuffs with lower porosities, higher primary porosities were occluded due to compaction, welding or secondary replacement or precipitation of new mineral phases (Dobson et al., 2003). However, an increase in permeability relative to porosity can be seen in partially and moderately welded tuffs. This increase in matrix permeability might be enhanced by fracture permeability during burial and tectonic activity (c.f. Feng, 2008). Densely welded tuffs and lavas have the lowest permeabilities. The partially very high porosity of up to $60 \%$ in lavas is ineffective porosity because possible reservoir spaces are isolated and not connected with each other, resulting in the low permeability values. Nevertheless, especially young lava fields can exhibit extremely high permeabilities and act as very efficient reservoirs or aquifers. The Snake River Plain aquifer in the United States occupies a Cenozoic stack of basaltic lavas up to $3 \mathrm{~km}$ thick (Greeley, 1982) and is one of the most permeable aquifer systems of the 
world (Hackett et al., 1986), with transmissivities in excess of 50,000 $\mathrm{m}^{2} /$ day (Welhan and Reed, 1997), i.e. permeabilities of up to $19,000 \mathrm{mD}$. In case of the densely welded tuffs the low permeability is explained as a result of a closing of the microfractures due to further compaction.

It is still to be tested in which way porosity and permeability of the rocks will be affected by increasing depth within the Valley of Mexico. It can be assumed that the volcaniclastic rocks within the Valley of Mexico were deposited in a comparable setting like the Tepoztlán Formation. Thus, lithofacies types, their stratigraphical stacking and lateral interfingering of architectural elements documented in outcrops (Lenhardt et al., in press) might be transferred to the subsurface, and the petrophysical rock properties of the Tepoztlán Formation presented here can be used to estimate the reservoir potential of the corresponding subsurface rocks of the Valley of Mexico in general. However, one also has to consider the burial history, diagenetic overprinting, distinct stress fields, and fracture permeabilities for a reliable reservoir prognosis.

\section{Conclusions}

Despite the wide distribution of volcanic rocks in Mexico, their reservoir potential has been overlooked in the past. Excellent outcrops of the Miocene Tepoztlán Formation enabled us to identify the petrophysical rock properties of characteristic deposits within a volcanic setting:

The lavas are characterized by the highest porosity values followed by tuffs, conglomerates, sandstones and tuffaceous breccias. On the contrary, the highest permeabilities within the Tepoztlán Formation rocks can be found in the conglomerates, followed by tuffs, tuffaceous breccias, sandstones and lavas. Furthermore, the knowledge of the spatio-temporal distribution of these deposits studied in outcrops provides important information on the reservoir potential ofcorresponding rocks in the subsurface and thus significantly advances our understanding of the reservoir characteristics of the Valley of Mexico and of volcanic settings in general. 
Future studies should focus on integrating petrophysical rock properties gained from outcrop analogue studies to 3D structural models of the subsurface, contributing to a more precise and descriptive reservoir prognosis of the Valley of Mexico.

\section{Acknowledgements}

N.L. acknowledges the University of Pretoria for its generous financial support. A.E.G. is grateful for financial support from the TU Darmstadt Energy Center. We thank Yixi Gu for translation of the Chinese literature and Holger Scheibner (both Technische Universität Darmstadt) for the preparation of thin sections and cutting of the rock samples. Grant Heiken is thanked for his comments on an early version of the manuscript and encouraging us to publish our data. Joan Marti, Rebecca C. Smyth, John M. Sharp Jr. and Patricia Sruoga are thanked for their constructive comments and very helpful reviews.

\section{References}

Anderson, L.A., 1994. Water permeability and related rock properties measured on core samples from the Yucca Mountain GU-3/G-3 and USW G-4 boreholes. U.S. Geological Survey Open-File Report 92-201, 36 pp.

Arellano, V.M., Torres, M.A., Barragán, R.M., 2005. Thermodynamic evolution of the Los Azufres, Mexico, geothermal reservoir from 1982 to 2002. Geothermics 34, 592-616.

Boivin, P., Livet, M., 2001. Les anneaux de tufs enfouis: une nouvelle cible pour la recherche de ressources en eau en terrain volcanique. L'exemple des captages de Vourzac (Devès, Massif central français). C. R. Acad. Sci. Paris, Sciences de la Terre et des planètes / Earth and Planetary Sciences 332, 761-767.

Bonnichsen, B., Kauffmann, D.F., 1987. Physical features of rhyolite lava flows in the Snake River Plain volcanic province, south-western Idaho. In: Fink, J.H. (Ed.), The emplacement of silicic domes and lava flows. Geol. Soc. Am. Spec. Pap. 212, 119-145. 
Branney, M.J., Kokelaar, P., 2002. Pyroclastic density currents and the sedimentation of ignimbrites. Mem. Geol. Soc. Lond. 27, 143 pp.

Breitkreuz, C., 1991. Fluviolacustrine sedimentation and volcanism in a late Carboniferous tensional intra-arc basin, northern Chile. Sed. Geol. 74, 173-187.

Capra, L., Macías, J.L., 2000. Pleistocene cohesive debris flows at Nevado de Toluca Volcano, central Mexico. J. Volcanol. Geotherm. Res. 102, 149-167.

Carapezza, M.L., Badalamenti, B., Cavarra, L., Scalzo, A., 2003. Gas hazard assessment in a densely inhabited area of Colli Albani Volcano (Cava dei Selci, Roma). J. Volcanol. Geotherm. Res. 123, 81-94.

Carranza, E.J.M., Wibowo, H., Barritt, S.D., Sumintadireja P., 2008. Spatial data analysis and integration for regional-scale geothermal potential mapping, West Java, Indonesia. Geothermics 37, 267-299.

Carrillo-Rivera, J.J., Cardona, A., Hergt, T., Huizar, A.R., Kobr, M., 1999. Marco geológico, hidrología subterráqnea, hidrogeoquímica, análisis geomorfológico y registros de temperatura en la subcuenca del río de las Avenidas. Final Report, CAASIM, Hidalgo, Mexico, 268 pp.

Cas, R.A.F., Wright, J.V., 1987. Volcanic successions - modern an ancient. Allen \& Unwin, London, 528 pp.

Chen, Z.Y., Huo, C.Y., Zhang, Z.W., 1999. Relationship between Tertiary volcanic rocks and hydrocarbons in the Liaohe basin, China. Am. Assoc. Petrol. Geol. Bull. 83, 10041014. 
Coussot, P., Meunier, M., 1996. Recognition, classification and mechanical description of debris flows. Earth-Sci. Rev. 40, 209-227.

De Cserna, Z., De la Fuente-Duch, M., Palacios-Nieto, M., Triay, L., Mitre-Salazar, L.M., Mota-Palomino, R., 1987. Estructura geológica-gravimetria sismicidad y relaciones neotectónicas regionales de la Cuenca de México. Univ. Nat. Autón. Méx. Inst. Geol. Bull. 104, 71.

Dobson, F., Kneafsey, T., Hulen, J., Simmons, A., 2003. Porosity, permeability and fluid flow in the Yellowstone geothermal system, Wyoming. J. Volcanol. Geotherm. Res. 123, 313-324.

Durazo, J., Farvolden, R.N., 1989. The groundwater regime of the Valley of Mexico from historic evidence and field observations. J. Hydrol. 112, 171-190.

Edmunds, W.M., Carrillo-Rivera, J.J., Cardona, A., 2002. Geochemical evolution of groundwater beneath Mexico City. J. Hydrol. 258, 1-24.

Ehrenberg, S.N., Nadeau, P.H., 2005. Sandstone vs. carbonate petroleum reservoirs: A global perspective on porosity-depth and porosity-permeability relationships. Am. Assoc. Petrol. Geol. Bull. 89, 435-445.

Feng, Z., 2006. Exploration potential of the large Qingshen gas field in the Songliao Basin. Natural Gas Industry 26(6), 1-5 (in Chinese).

Feng, Z., 2008. Volcanic rocks as prolific gas reservoir: A case study from the Qingshen gas field in the Songliao Basin, NE China. Mar. Petrol. Geol. 25, 416-432.

Ferrari, L., López Martínez, M., Gonzalez Cervantes, N., Jacobo Albarrán J., Hernandez Bernal, M., 2003. Volcanic record and age of formation of the Mexico City Basin. GSA Cordilleran Meeting, Pto. Vallarta. 
Fisher, R.V., 1961. Proposed classification of volcaniclastic sediments and rocks. Bull. Geol. Soc. Am. 72, 1409-1414.

Flint, L.E., Selker, J.S., 2003. Use of porosity to estimate hydraulic properties of volcanic tuffs. Advances in Water Resources, 26, 561-571.

Foster, S.S.D., Ellis, A.T., Locilla-Penon, M., Rodriguez-Estrada, H.V., 1985. Role of volcanic tuffs in ground-water regime of Valle Central, Costa Rica: Ground Water 23(6), 795-801.

Fridrich, C.J., Dudley Jr., W.W., Struckless, J.S., 1994. Hydrogeologic analysis of the saturated-zone ground-water system, under Yucca Mountain, Nevada. J. Hydrol. 154, 133-168.

García-Palomo, A., Macías, J.L., Garduno, V.H., 2000. Miocene to recent structural evolution of the Nevado de Toluca volcano region, Central Mexico. Tectonophysics 318, 281-302.

García-Palomo, A., Macías, J.L., Arce, J.L., Capra, L., Garduño, V.H., Espíndola, J.M., 2002. Geology of Nevado de Toluca Volcano and surrounding areas, central Mexico: Boulder, Colorado, Geol. Soc. Am. Map and Chart Series MCH089, pp. 1-26.

Goggin, D.J., Thrasher, R.L., Lake, L.W., 1988. A theoretical and experimental analysis of minipermeameter response including gas slippage and high velocity flow effects. In Situ 12, 79-116.

Greeley, R., 1982. The Snake River Plain, Idaho - representative of a new category of volcanism. J. Geophys. Res. 87, 2705-2712. 
Guo, Z.Q., 2001. Hydrocarbon prospects of volcanic rocks in southern coastal waters of China judged by the distribution of global oil and gas field. Petroleum Geology and Experiments 23, 122-132 (in Chinese).

Hackett, W., Pelton, J., Brockway, C., 1986. Geohydrologic story of the Eastern Snake River Plain and the Idaho National Engineering Laboratory. U.S. Department of Energy, Idaho National Engineering Laboratory, 32 pp.

Hampton, M.A., 1975. Competence of fine-grained debris flows. J. Sediment. Petrol. 45, 834-844.

Harms, J.C., Southard, J.B., Spearing, D.R., Walker, R.G., 1982. Depositional environments as interpreted from primary sedimentary structures and stratification sequences. Lecture Notes, Soc. Econ. Paleontol. Mineral., Short Course 2, Dallas, 161 pp.

Hinterwimmer, G., 2002. Los reservorios de la Serie Tobífera. In: Schiuma, M., Hinterwimmer, G., Vergani, G. (Eds.), Rocas reservorio de las cuencas productivas de la Argentina. V Congreso de Exploratción y Desarrollo de Hidrocarburos. Instituto Argentino de Petroleo y Gas, Bs. As., 27-47.

Jinglan, L., Chengli, Z., Zhihao, Q., 1999. Volcanic reservoir rocks: A case study of the Cretaceous Fenghuadian Suite, Huanghua Basin, Eastern China. J. Pet. Geol. 22, 397416.

Johnson, A.M., Rodine, J.R., 1984. Debris Flow. In: Brunsden, D., Prior, D.B. (Eds.), Slope Instability, Wiley, Chichester, pp. 257-361.

Kataoka, K., 2005. Distal fluvio-lacustrine volcaniclastic resedimentation in response to an explosive silicic eruption: The Pliocene Mushono tephra bed, Central Japan. Geol. Soc. Am. Bull. 117, 3-17. 
Lenhardt, N., 2009. Volcaniclastic successions of the southern edge of the Transmexican Volcanic Belt: evidence for the Miocene plate reorganisation in Central America (Morelos, Mexico). Ph.D. Thesis, Darmstadt University of Technology, 141 pp. URL: http://tuprints.ulb.tu-darmstadt.de/1405/

Lenhardt, N., Böhnel, H., Wemmer, K., Torres-Alvarado, I.S., Hornung, J., Hinderer, M., 2010. Petrology, magnetostratigraphy and geochronology of the Miocene volcaniclastic Tepoztlán Formation: implications for the initiation of the Transmexican Volcanic Belt (Central Mexico). Bull. Volcanol., 72, 817-832.

Lenhardt, N., Hornung, J., Hinderer, M., Böhnel, H., Torres-Alvarado, I.S., Trauth, N., in press. Build-up and depositional dynamics of an arc front volcaniclastic complex: The Miocene Tepoztlán Formation (Transmexican Volcanic Belt, Central Mexico). Sedimentology, doi: 10.1111/j.1365-3091.2010.01203.x.

Levin, L.E., 1995. Volcanogenic and volcaniclastic reservoir rocks in MesozoicCenozoic island arcs: examples from the Caucasus and the NW Pacific. Journal of Petroleum Geology 18(3), 267-288.

Lucia, F.J., 2007. Carbonate Reservoir Characterization. $2^{\text {nd }}$ ed., Springer, Berlin, 336 pp.

Luo, J.L., Zhang, C.L., Qu, Z.H., 1999. Volcanic reservoir rocks: a case study of the Cretaceous Fenghuadian Group, Huanghua Basin, eastern China. J. Pet. Geol. 22, $397-$ 415.

Luo, J.L., Morad, S., Liang, Z.G., Zhu, Y.S., 2005. Controls on the quality of Archean metamorphic and Jurassic volcanic reservoir rocks from the Xinglongtai buried hill, western depression of Liaohe basin, China. Am. Assoc. Petrol. Geol. Bull. 89, 13191346.

MacDonald, G.A., 1972. Volcanoes. Prentice-Hall, Engelwood Cliffs, NJ, 510 pp. 
Manville, V., Németh, K., Kano, K., 2009. Source to sink: A review of three decades of progress in the understanding of volcaniclastic processes, deposits, and hazards. Sed. Geol. 220, 136-161.

Marsal, R.J., Graue, R., 1969. El subsuelo del lago de Texcoco. In: Nabor, C. (Ed.), El hundimiento de la Ciudad de México y Proyecto Texcoco, México, D.F.. Secretaría de Hacienda y Crédito Público, pp. 167-202.

Mathisen, M.E., McPherson, J.G., 1991. Volcaniclastic deposits: implications for hydrocarbon exploration. In: Fisher, R.V., Smith, G.A. (Eds.), Sedimentation in Volcanic Settings. SEPM Spec. Publ., 45, Tulsa, Ok, pp. 27-36.

McPhie, J., Doyle, M., Allen, R., 1993. Volcanic textures - a guide to the interpretation of textures in volcanic rocks. Centre for Ore Deposit and Exploration Studies, University of Tasmania, $198 \mathrm{pp}$.

Miall, A.D., 1977. A review of the braided river depositional environment. Earth Sci. Rev. 13, 1-62.

Miall, A.D., 1978. Lithofacies types and vertical profile models in braided rivers: a summary. Can. Soc. Pet. Geol. Mem. 5, 597-604

Miall, A.D., 1985. Architectural-element analysis: a new method of facies analysis applied to fluvial deposits. Earth Sci. Rev. 22, 261-308.

Miall, A.D., 1996. The Geology of Fluvial Deposits. Springer-Verlag, Berlin, 581 pp.

Mitsuhata, Y., Matsuo, K., Minegishi, M., 1999. Magnetotelluric survey for exploration of a volcanic-rock reservoir in the Yurihara oil and gas field, Japan. Geophysical Prospecting 47(2), 195-218. 
Mooser, F., Molina, C., 1993. Estratigrafia y estructuras del valle de Mexico. Proceedings of Symposium: El subsuelo de la Ciudad de Mexico y su relacion con la ingeniera de cimentaciones., A cinco anos del sismo de 1985. SMMS, Mexico DF.

Mooser, F., Montiel, A., Zúniga, Á., 1996. Nueva mapa geológica de las cuencas de México, Toluca y Puebla - Estratigrafía, tectónica regional y aspectos geotérmicos. Comision Federal de Electricidad, 27 pp.

Mueller, W., 1991. Volcanism and related slope to shallow marine volcaniclastic sedimentation: an Archean example Chibougamau, Quebec, Canada. Precamb. Res. 49, $1-22$.

Nakata, J.K., 1980. Distribution and petrology of the Anderson-Coyote Reservoir volcanic rocks, California. Open-File Report - U.S. Geological Survey, 130 pp.

Neeper, D.A., Gilkeson, R.H., 1996. The influence of topography, stratigraphy, and barometric venting on the hydrology of unsaturated Bandelier Tuff, Jemez Mountains Region, in: Goff, F., et al., eds., New Mexico Geological Society Guidebook 47: Socorro, New Mexico, New Mexico Geological Society, 427-432.

Neretnieks, I., 1980. Diffusion in the rock matrix; an important factor in radionuclide retardation? J. Geophys. Res. 85, 4379-4397.

Ortega, A., Farvolden, R.N., 1989. Computer analysis of regional groundwater flow and boundary conditions in the Basin of Mexico. J. Hydrol. 110, 271-294.

Orton, G.J., 1996. Volcanic environments. In: Reading, H.G. (Ed.), Sedimentary Environments: Processes, Facies and Stratigraphy Reading. Blackwell Science, Oxford, pp. 485-567. 
Peterman, Z.E., Struckless, J.S., Mahan, S.A., Marshall, B.D., Gutentag, E.D., Downey, J.S., 1992. Strontium isotope characterization of the Ash Meadows ground-water system, southern Nevada. In: Kharaka, Y.K., Maest, A.S. (Eds.), Water-Rock Interaction: Proc. 7th Water Rock Interaction Symp., Utah, USA. Balkema, Rotterdam, pp. 825-829.

Peterson, D.W., 1979. Significance of the flattening of pumice fragments in ash-flow tuffs. In: Chapin, C.E., Elston, W.E. (Eds.) Ash-flow tuffs. Geol. Soc. Am. Spec. Pap., 195-204.

Pierson, T.C., Daag, A.S., Reyes, P.J.D., Regalado, M.T.M., Solidum, R.U., Tubianosa, B.S., 1996. Flow and deposition of post-eruption hot lahars on the east side of Mount Pinatubo, July-October 1991. In: Newhall, C.G., Punongbayan, R.S. (Eds.), Fire and Mud, Eruptions and Lahars of Mount Pinatubo, Philippines. Philippines Institute of Volcanology and Seismology, Univ. Washington Press., pp. 921-950.

Quane, S., Russel, J.K., 2005. Ranking welding intensity in pyroclastic deposits. Bull. Volcanol. 67, 129-143.

Ragan, D.H., Sheridan, M.F., 1972. Compaction of the Bishop Tuff, California. Bull. Geol. Soc. Am. 83, 95-106.

Ross, G.S., Smith, R.L., 1961. Ash-flow tuffs: Their origins, geological relations and identification: USGS Prof. Pap. 366, 56 pp.

Rust, A.C., Russel, J.K., 2000. Detection of welding in pyroclastic flows with ground penetrating radar: insights from field and forward modelling data. J. Volcanol. Geotherm. Res. 95, 23-34.

Sakata, S., Takahashi, M., Igari, S.I., Noriyuki, S., 1989. Origin of light hydrocarbons from volcanic rocks in the "Green Tuff"' region of northeast Japan: biogenic versus magmatic. Chem. Geol. 74, 241-248. 
Sembodo, I., 1973. Notes on formation evaluation in the Jatibarang volcanic reservoir. In: Proceedings of the Annual Convention - Indonesian Petroleum Association, pp. 131-147.

Sheridan, M.F., Ragan, D.M., 1976. Compaction of ash-flow tuffs. In: Chilingarian, G.V., Wolf, K.H. (Eds.), Compaction of coarse-grained sediments, II. Elsevier, Amsterdam, pp. $677-717$.

Shimazu, M., 1985. Altered rhyolites as oil and gas reservoirs in the Minaminagaoka Gas Field (Niigata Prefecture, Japan). Chem. Geol. 49, 363-370.

Siegenthaler, C., Huggenberger, P., 1993. Pleistocene Rhine gravel: deposits of a braided river system with dominant pool preservation. In: Best, J.L., Bristow, C.S. (Eds.), Braided Rivers. Geol. Soc. Spec. Publ. 75, 147-162.

Smith, R.L., 1960. Zones and zonal variations in welded ash flows. USGS Prof. Pap. 354F, 149-159.

Smith, S.A., 1990. The sedimentology and accretionary style of an ancient gravel-bed stream: the Budleigh Salterton Pebble Beds (Lower Triassic), southwest England. Sed. Geol. 67, 199-219.

Smith, G.A., Lowe, D.R., 1991. Lahars: volcano-hydrologic events and deposition in the debris flow - hyperconcentrated flow continuum. In: Fisher, R.V., Smith, G.A (Eds.), Sedimentation in Volcanic Settings. Soc. Econ. Paleontol. Mineral., Spec. Publ. 45, 5970.

Smyth-Boulton, R.C., 1995. Porosity and permeability controls in the Santana ash-flow tuff, Trans-Pecos Texas. M.A. Thesis, Department of Geological Sciences, University of Texas at Austin, 100 pp. 
Smyth, R.C., Sharp, J.M., Jr., 2006. The hydrology of tuffs. In: Heiken, G. (Ed.), Tuffs their properties, uses, hydrology, and resources. Geol. Soc. Am. Spec. Pap. 408, pp. 91111.

Sparks, R.S.J., 1976. Grain size variations in ignimbrites and implications for the transport of pyroclastic flows. Sedimentology 23, 147-188.

Sruoga, P., Rubinstein, N., 2002. Procesis deutéricos y diagenéticos en volcanitas de la Provincia Chon Aike, Santa Cruz, Argentina. Implicancia en el desarrollo de la porosidad y permeabilidad: $15^{\circ}$ Congreso Geológico Argentino, 2, p. 9-14.

Sruoga, P., Rubinstein, N., 2007. Processes controlling porosity and permeability in volcanic reservoirs from the Austral and Neuquén basins, Argentina. AAPG Bull. 91, 115-129.

Sruoga, P., Rubinstein, N., Hinterwimmer, G., 2004. Porosity and permeability in volcanic rocks: a case study on the Serie Tobífera, South Patagonia, Argentina. J. Volcanol. Geotherm. Res. 132, 31-43.

Steel, R.J., Thompson, D.B., 1983. Structures and textures in Triassic braided stream conglomerates ('Bunter' Pebble Beds) in the Sherwood Sandstone Group, North Staffordshire, England. Sedimentology 30, 341-367.

Stetzenbach, K.J., Hodge, V.F., Guo, C., Farnham, I.M., Johannesson, K.H., 2001. Geochemical and statistical evidence of deep carbonate groundwater within overlying volcanic rock aquifers/aquitards of southern Nevada, USA. J. Hydrol. 243, 254-271.

Stimac, J.A., Powell, T.S., Golla, G.U., 2004. Porosity and permeability of the Tiwi geothermal field, Philippines, based on continuous and spot core measurements. Geothermics 33, 87-107. 
Streck, M.J., Grunder, A.L., 1995. Crystallization and welding variations in a wide ignimbrite sheet; the Rattlesnake Tuff, eastern Oregon, USA. Bull. Volcanol. 57, 151169.

Tang, H., 2006. Incorporation of spatial characteristics into volcanic facies and favorable reservoir prediction. SPE Reservoir Evaluation \& Engineering 9(4), 565-573.

Todd, S.P., 1996. Process deduction from fluvial sedimentary structures. In: Carling, P.A., Dawson, M.R. (Eds.), Advances in Fluvial Dynamics and Stratigraphy. Wiley, Chichester, pp. 299-350.

Vázquez-Sánchez, E., Jaimes-Palomera, R., 1989. Geología de la Cuenca de México. Geofís. Int. 28, 133-190.

Vincent, P., 2000. Volcanoes: From magmas to tephra and epivolcaniclastics. In: Leyrit, H., Montenat, C. (Eds.), Volcaniclastic rocks from magmas to sediments, Gordon and Breach Science Publishers, Amsterdam, pp. 1-32.

Vinciguerra, S., Del Gaudio, P., Mariucci, M.T., Marra, F., Meredith, P.G., Montone, P., Pierdominici, S., Scarlato, P., 2009. Physical properties of tuffs from a scientific borehole at Alban hills volcanic district (central Italy). Tectonophysics 471, 161-169.

Walker, R.G., Cant, D.J., 1984. Sandy fluvial systems. In: Walker, R.G. (Ed.), Facies Models, $2^{\text {nd }}$ edition, Geoscience Canada Reprint Series 1, 71-89.

Wang, H.B., Wang, P.J., Chen, H., Wang, S.X., Qu, Y.B., 1997. Volcanic rock reservoirs of Cenozoic and oil-gas occurrence in the Lower Liaohe Depression. Journal of Changchun University of Earth Science 27 (Suppl. II), 49-53 (in Chinese). 
Wang, P.J., Chen, S.M., Liu, W.Z., Shan, X.L., Cheng, R.H., Zhang, Y., Wu, H.B., Qi, J.S., 2003a. Relationship between volcanic facies and volcanic reservoirs in SongLiao basin. Oil \& Gas Geology 24(1), 18-23 (in Chinese).

Wang, P.J., Chi, Y.L., Liu, W.Z., 2003b. Volcanic facies of the Songliao Basin: classification, characteristics and reservoir significance. Journal of Jilin University (Earth Science Edition) 33(4), 449-456 (in Chinese).

Wang, P.J., Feng, Z.Q., Mattern, F., 2003c. Reservoir volcanic rocks: geology and geochemistry, the Mesozoic non-marine Songliao Basin, NE China. Journal of Geoscience Research in NE Asia 16(2), 129-137.

Wang, C., Hou, G., Li, J., 2008. Analysis on the factors to control the reservoir capabilities of the volcanic rocks in the Daqing Oilfield, China. In: Zheng, Y., Hou, G. (Eds), Extension tectonics in China. Journal of the Virtual Explorer (electronic edition) 29 , pp. 1.

Welhan, J.A., Reed, M.F., 1997. Geostatistical analysis of regional hydraulic conductivity variations in the Snake River Plain Aquifer, Eastern Idaho. Bull. Geol. Soc. Am. 109, 855-868.

White, J.D.L., Houghton, B.F., 2006. Primary volcaniclastic rocks. Bull. Geol. Soc. Am. 34, 677-680.

Williams, H., McBirney, A.R., 1979. Volcanology. Freeman and Cooper, San Francisco, Calif., 391 pp.

Wilson, C.J.N., Hildreth, W., 2003. Assembling an ignimbrite: mechanical and thermal building blocks in the Bishop Tuff, California. J. Geol., 111, 653-670. 
Wilson, C.J.N., Walker, G.P.L., 1982. Ignimbrite depositional facies: the anatomy of a pyroclastic flow. J. Geol. Soc. Lond. 139, 581-592.

Winograd, I.J., 1971. Hydrogeology of ash-flow tuff: A preliminary statement. Water Resour. Res. 7, 994-1006.

Winograd, I.J., Thordarson, W., 1975. Hydrogeologic and hydrochemical framework, south-central Great Basin, Nevada, California, with special reference to the Nevada Test Site. U.S. Geol. Surv. Prof. Pap., 712-C, 125 pp.

Yagi, M., Ohguchi, T., Akiba, F., Baba, K., Yoshida, T., Tiba, T., 2009. The Fukuyama Volcanic Rocks: an oil-producing submarine composite volcano in the Late Miocene to Early Pliocene Akita-Yamagata back-arc basin, NE Honshu, Japan. Sed. Geol. 220, 243255.

Zhang, Z., Wu, B., 1994. An overview on volcanic reservoirs and exploration technologies. Gas Exploration and Development 16 (1), 1-23 (in Chinese). 